\title{
Vertical movements of the Murono mud volcano in Japan caused by the Naganoken Kamishiro Fault Earthquake in 2014
}

\author{
Shigekazu Kusumoto ${ }^{1 *}$, Toshiki Hamamoto ${ }^{2}$, Yoichi Fukuda ${ }^{3}$ and Atsushi Takahashi ${ }^{3}$
}

\begin{abstract}
We observed vertical movements of the Murono mud volcano, Niigata, Japan, caused by the Naganoken Kamishiro Fault Earthquake $(M=6.7)$ on 22 November 2014. Precise levelling around the mud volcano was carried out on 27 November 2014, and the obtained elevation was compared with the data obtained for 11 November 2014. It was found that an elliptical uplift area, about $46 \mathrm{~mm}$ in magnitude and an order of magnitude smaller than that of the ones formed due to the past movements caused by the earthquakes in the same area, had been formed. It was considered that the structures of the shallow subsurface as well as the distance between the mud volcano and epicentre might play an important role in understanding the magnitude of vertical movements and distribution patterns.
\end{abstract}

Keywords: Mud volcano; Vertical movement; Levelling; Naganoken Kamishiro Fault Earthquake; Murono mud volcano

\section{Findings}

Introduction

Mud volcanoes develop at convergent plate margins and are usually located around the crests of anticlines in fold and thrust belts (e.g. Chigira and Tanaka 1997; Fowler et al. 2000; Bonini 2007; Morley 2007). They are useful indicators of stress orientation and tectonic controls (e.g. Bonini and Mazzarini 2010; Bonini 2012) and are a natural source of atmospheric methane that is a powerful greenhouse gas (e.g. Dimitrov 2003; Etiope and Milkov 2004; Etiope et al. 2008). Although most of them are normally in a dormant stage, their dormant stage activities are characterized by vigorous seepage of water, gas and petroleum, and many various observations have been carried out in order to elucidate their origins and/or processes (e.g. Deville and Guerlais 2009; Mazzini et al. 2009a; Rudolph and Manga 2010; Antonielli et al. 2014; Kusumoto et al. 2014).

It is known that mud volcanoes become active by external events such as occurrence of large earthquakes in the neighbourhood, drilling and other activities (e.g. Chigira and Tanaka 1997; Panahi 2005; Mellors et al. 2007;

\footnotetext{
* Correspondence: kusu@sci.u-toyama.ac.jp

1 Graduate School of Science and Engineering for Research (Science),

University of Toyama, 3910 Gofuku, Toyama 930-8555, Japan

Full list of author information is available at the end of the article
}

Davies et al. 2008; Manga et al. 2009; Mazzini et al. 2009b; Sawolo et al. 2009, 2010). The Murono mud volcano, studied by us (Figure 1), is no exception; a local GPS survey detected a vertical movement of $400 \mathrm{~mm}$ caused by the Niigataken Chuetsu-oki Earthquake in 2007 (Figure 1, $M=6.8$ ) (Onishi et al. 2009). In addition, Matta et al. (2012) observed an elliptical uplift area, reaching a maximum height of $400 \mathrm{~mm}$, through Lidar survey after the 2011 Naganoken Hokubu Earthquake (Figure 1, $M=6.7$ ).

The Murono mud volcano is located in the vicinity of an unnamed anticline limb near the Naradate syncline (Figure 1) (e.g. Noda 1962), in an area known as Niigata basin. The Niigata basin is characterized by many fold structures in the NE-SW direction and is one of the most important areas for oil production in Japan. In addition to these geological characteristics, it is known that the Murono mud volcano is located in a strain concentration belt (e.g. Sagiya et al. 2000). This strain concentration belt, called Niigata Kobe Tectonic Zone, has a strain rate of approximately $0.1 \mathrm{ppm} /$ year, a value that is an order of magnitude larger than that of other areas of Japan (approximately $0.01 \mathrm{ppm} /$ year); large earthquakes such as the 1995 Southern Hyogo Prefecture Earthquake $(M=7.3)$, the 2007 Niigataken Chuetsu-oki Earthquake ( $M=6.8)$ and other earthquakes of $M>6$ occurred in this strain concentration belt. 


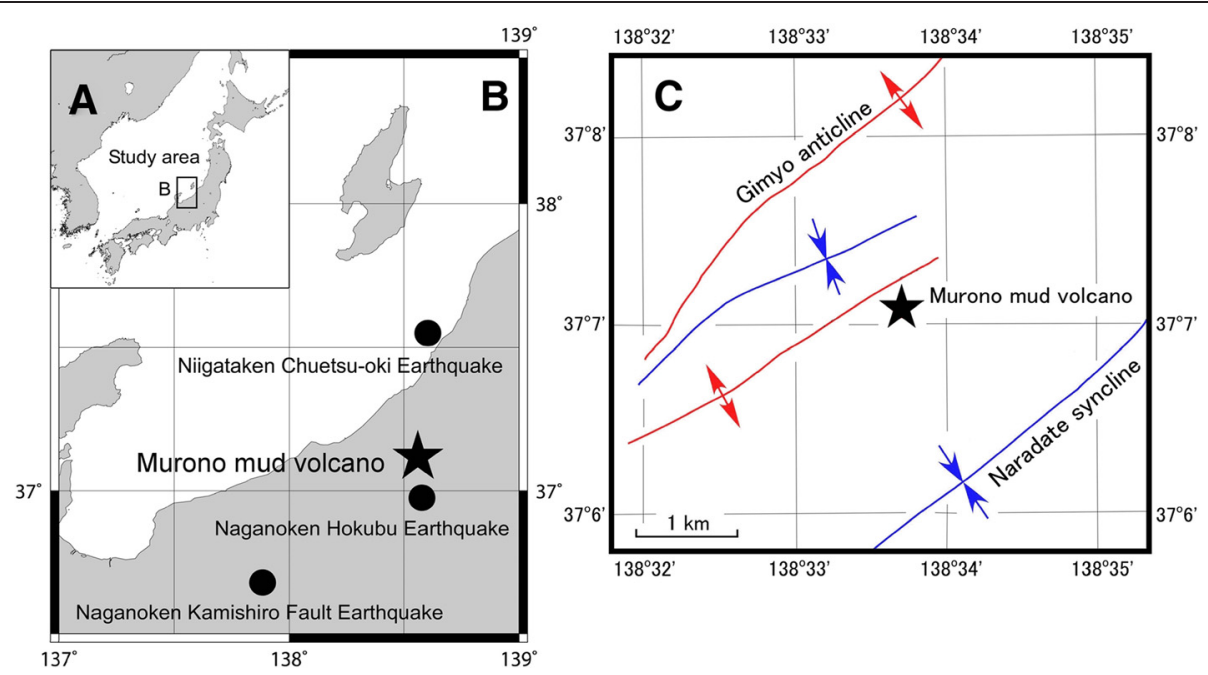

Figure 1 Location of Murono mud volcano, Niigata, Japan. (A) Location of the study area in the back-arc region, central Japan. (B) Positional relationship among the Murono mud volcano, the Naganoken Kamishiro Fault Earthquake $(M=6.7)$, the Naganoken Hokubu Earthquake $(M=6.7)$ and the Niigataken Chuetsu-oki Earthquake ( $M=6.8$ ). (C) Location of the Murono mud volcano and distribution of folds (after Takeuchi et al. 2000). Red and blue lines indicate anticline and syncline structures, respectively.

The Naganoken Kamishiro Fault Earthquake that occurred on 22 November 2014 was located in the strain concentration belt; the Kamishiro Fault is a part of the Itoigawa-Shizuoka Tectonic Line (e.g. Research Group for Active Faults 1991). Its magnitude $(M)$ and hypocentre were 6.7 and at a depth of about $5 \mathrm{~km}$, respectively (Japan Meteorological Agency 2014). The distance between the epicentre of this earthquake and the Murono mud volcano was about $76 \mathrm{~km}$.

Given the past observational evidences mentioned above and due to a probability of occurrence of a similar type of movements as shown by Onishi et al. (2009) and/or Matta et al. (2012), we have carried out a periodic, precise levelling since 2012 to i) observe interseismic vertical movements as an indication of the status of the mud volcano at rest and ii) examine the source of any conspicuous vertical movements (Kusumoto et al. 2014). This year, we conducted the scheduled levelling in June and November. The last levelling was carried out on 11 November, and the Naganoken Kamishiro Fault Earthquake occurred 11 days later.

In this paper, we report vertical movements of the Murono mud volcano caused by the Naganoken Kamishiro Fault Earthquake, obtained by the precise levelling carried out on 27 November.

\section{Observation and data processing}

We carried out the precise levelling with an automatic digital level using 60 points as benchmarks (Figure 2), and then repeating the procedure on 27 November 2014, after the Naganoken Kamishiro Fault Earthquake. These benchmarks were set up in 2012 and were connected via 12 levelling routes (Kusumoto et al. 2014); the scheduled precise levelling was carried out on these benchmarks and the survey of each levelling route was performed so that the round trip difference was zero. Incidentally, the last precise levelling scheduled for this year was conducted just before the earthquake, on 11 November 2014.

Each elevation was determined by geodetic net adjustment (e.g. Bonford 2012) referenced to the elevation of A0, the datum point which was determined by levelling from a second-order benchmark (BM2167-7) provided by the Geographical Survey Institute of Japan. The standard deviations of our levelling on 27 and 11 November 2014 were 0.08 and $0.10 \mathrm{~mm}$, respectively.

\section{Result}

Figure 3 shows the vertical movement of the ground that was obtained by subtracting the elevations observed on 11 November from the ones obtained on 27 November. It can be observed that the entire zone experienced an uplift and that there are two conspicuous uplift areas.

The first uplift area is around the centre (A42 to A46); this uplift area is elliptical in shape with major and minor axes of about 80 and $40 \mathrm{~m}$, respectively (estimations from a contour line of $15-\mathrm{mm}$ uplift). The maximum magnitude of the uplift is $46 \mathrm{~mm}$. The second one is located in the eastern part of the study area (A1 to A9), and the maximum magnitude of uplift is $32 \mathrm{~mm}$. These uplift areas enclose a zone (A10 to A15 and A60) where, in contrast, a subsidence of less than about $5 \mathrm{~mm}$ was observed. 


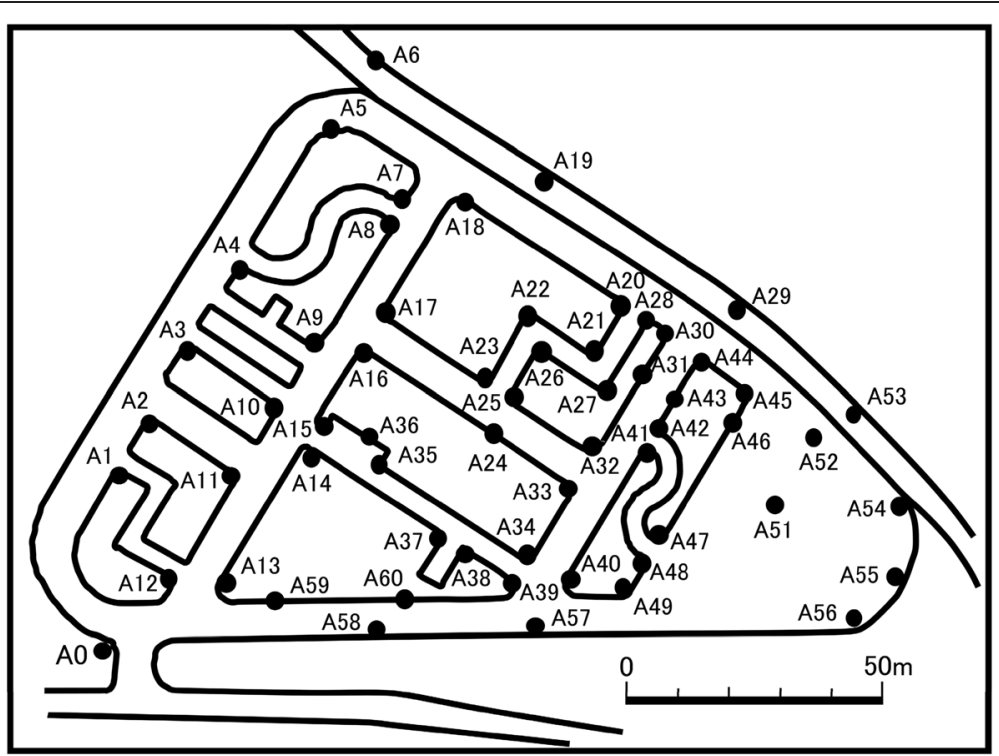

Figure 2 Distribution of benchmarks (60 points: A0 to A60). The benchmark A50 was accidently removed from the 11 November 2014 survey.

\section{Discussion}

In order to clarify whether or not the observed vertical movements were caused by the Naganoken Kamishiro Fault Earthquake, we retrieved the earthquake data for the period of 11 to 27 November (source: Japan Metrological Agency 2014). Of all the earthquakes that occurred during this period, the Naganoken Kamishiro Fault Earthquake was the only one exceeding $M=6$; earthquakes falling in the $M=5$ class occurred at distances of at least $200 \mathrm{~km}$ away from the Murono mud volcano (Table 1).

Information regarding date, magnitude and hypocentre information for the earthquakes was retrieved from the web site of Japan Meteorological Agency (2014).
The distances were calculated as horizontal surface distance between the epicentre of the earthquakes and the Murono mud volcano $\left(37^{\circ} 7^{\prime} 16.41^{\prime \prime} \mathrm{N}, 138^{\circ} 33^{\prime} 30.31^{\prime \prime} \mathrm{E}\right)$.

Manga et al. (2009) proved a correlation between the magnitude and hypocentral distance of earthquakes and triggered mud volcano eruptions; in addition, Manga et al. (2009) showed that the triggerable condition of the mud volcano follows the empirical condition curve for the occurrence of liquefaction as in Wang et al. (2006). This curve indicates that an earthquake with high magnitude can activate a distant mud volcano; as an example, an earthquake of $M=5$ can trigger a mud volcano at a distance of $20 \mathrm{~km}$ from its hypocentre, while an earthquake

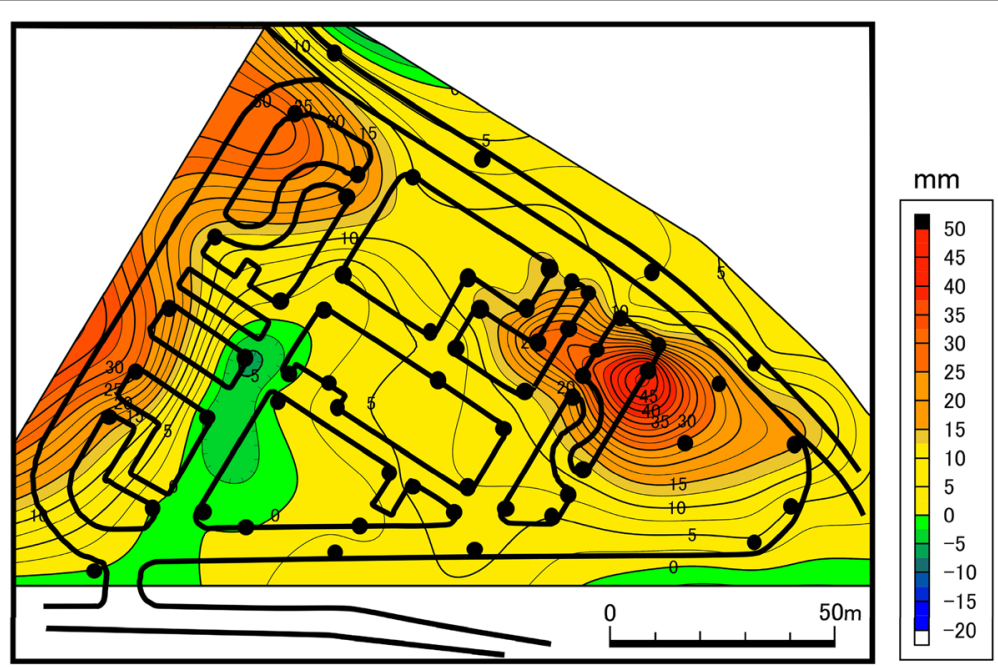

Figure 3 Vertical movements during 11 to 27 November 2014. Displacements are in millimetres, and the contour interval is $2.5 \mathrm{~mm}$. Point A0 is assumed to be fixed. 
Table 1 Earthquake data $(M \geq 5.0)$ from 11 to 27 November 2014

\begin{tabular}{|c|c|c|c|c|c|c|}
\hline Number & Date & Latitude & Longitude & Depth (km) & $M$ & Distance (km) \\
\hline 1 & 22 & $36^{\circ} 41.5^{\prime} \mathrm{N}$ & $137^{\circ} 53.4^{\prime} \mathrm{E}$ & 5 & 6.7 & 76 \\
\hline 2 & 20 & $37^{\circ} 20.2^{\prime} \mathrm{N}$ & $141^{\circ} 34.7^{\prime} \mathrm{E}$ & 46 & 5.5 & 269 \\
\hline 3 & 21 & $20^{\circ} 48.0^{\prime} \mathrm{N}$ & $120^{\circ} 18.9^{\prime} \mathrm{E}$ & 0 & 5.5 & 2,527 \\
\hline 4 & 14 & $45^{\circ} 17.2^{\prime} \mathrm{N}$ & $151^{\circ} 23.1^{\prime} \mathrm{E}$ & 30 & 5.4 & 1,404 \\
\hline 5 & 18 & $20^{\circ} 53.2^{\prime} \mathrm{N}$ & $121^{\circ} 25.5^{\prime} \mathrm{E}$ & 0 & 5.3 & 2,446 \\
\hline 6 & 20 & $24^{\circ} 52.8^{\prime} \mathrm{N}$ & $122^{\circ} 0.2^{\prime} \mathrm{E}$ & 46 & 5.3 & 2,078 \\
\hline 7 & 23 & $39^{\circ} 36.3^{\prime} \mathrm{N}$ & $143^{\circ} 34.0^{\prime} \mathrm{E}$ & 31 & 5.1 & 517 \\
\hline 8 & 18 & $24^{\circ} 59.0^{\prime} \mathrm{N}$ & $123^{\circ} 34.1^{\prime} \mathrm{E}$ & 13 & 5.0 & 1,959 \\
\hline
\end{tabular}

of $M=6$ can trigger a mud volcano at a distance of $60 \mathrm{~km}$ from the hypocentre. Consequently, earthquakes of $M=5$ class at more than $200 \mathrm{~km}$ distance from the Murono mud volcano could not have caused its eruption; therefore, we can conclude that the vertical movements of the ground shown in Figure 3 were caused by the Naganoken Kamishiro Fault Earthquake $(M=6.7)$ on 22 November 2014.

As mentioned above, the Murono mud volcano has experienced conspicuous uplifts due to three large earthquakes occurring in the neighbourhood since 2007 (including the one in this study); the Naganoken Kamishiro Fault Earthquake was almost the same in magnitude as the Niigataken Chuetsu-oki Earthquake and the Naganoken Hokubu Earthquake. However, the amount of vertical movement we observed was a tenth of the uplift observed after each of the past earthquakes.

The Murono mud volcano has a distance of about 49 $\mathrm{km}$ from the Niigata Chuetsu-oki Earthquake, about 16 $\mathrm{km}$ from the Naganoken Hokubu Earthquake, and about $76 \mathrm{~km}$ from the Naganoken Kamishiro Fault Earthquake. Although the Naganoken Kamishiro Fault Earthquake has the same magnitude as the Naganoken Hokubu Earthquake, there is a large difference (about five times) in the distance between the epicentre and the mud volcano. Therefore, we suggest that the distance between the mud volcano and epicentre (or hypocentre) would control the activation intensity or magnitude of eruption of the mud volcano.

In contrast, despite being located at a greater distance, the Niigataken Chuetsu-oki Earthquake caused the same vertical movements as the Naganoken Hokubu Earthquake in the mud volcano. Since the seaside area in the Niigata basin has a thick sedimentary layer, this might suggest that the geological setting and structure can affect vertical movements. In the future, it will be necessary to discuss subsurface structures when correlating the activity of mud volcano and earthquakes; in fact, the eruption of mud volcanoes can be triggered by seismic waves whose amplitude is affected by subsurface structures (e.g. Manga et al. 2009).
Conspicuous uplift around the central area corresponds to the past uplift due to neighbouring large earthquakes (e.g. Onishi et al. 2009; Matta et al. 2012) and has also been recognized as an uplift area during the quiescent phase (Kusumoto et al. 2014). Despite the small size of the mud volcano, it is interesting that the conspicuous uplift due to neighbouring large earthquakes occurred at the specific area and that the area undergoes an uplift during the quiescent phase; during this phase, a repetition of uplift and subsidence is observed within a period of around a month. A possible explanation of the recurrent uplift and subsidence each month in the quiescent phase can be the change in overpressure due to the flow of mud in the shallow layers (Kusumoto et al. 2014). From these observational evidences, we suggest that structures in the shallow subsurface would give some restrictions to the movement of the fluid mud, resulting in the uplift of the specific area. In order to clarify the origin of conspicuous uplifts due to neighbouring large earthquakes, it is necessary to estimate detailed, threedimensional subsurface structures of this mud volcano in the future.

\section{Conclusion}

We carried out the precise levelling in the mud volcano on 27 November 2014 after the Naganoken Kamishiro Fault Earthquake of 22 November 2014 and compared the observed elevations with the precise levelling results on 11 November 2014.

We found that an elliptical uplift area of about $46 \mathrm{~mm}$, corresponding to the uplift areas caused by the large, neighbouring earthquakes in the past, had been formed. Although it was clarified that the observed vertical movements were caused by the Naganoken Kamishiro Fault Earthquake, their magnitudes were an order of magnitude smaller than those of the vertical movements caused due to past earthquakes. Therefore, it was suggested that the distance between the mud volcano and epicentre (or hypocentre) of the earthquakes controls the activity of the mud volcano. 
In addition, as an explanation of the conspicuous uplifts due to large, neighbouring earthquakes occurring in small specific areas, we suggested that structures of the shallow subsurface would control the formation and distribution of the uplift areas.

\section{Competing interests}

The authors declare that they have no competing interests.

\section{Authors' contributions}

SK planned this study and acquired data. He also confirmed the analysed data and drafted this manuscript. TH acquired the levelling data and analysed the datasets. YF acquired the data and discussed the results we observed. AT observed benchmarks by Total Station and decided their position precisely. All authors read and approved the final manuscript.

\section{Authors' information}

SK is an associate professor of the University of Toyama. TH is a student of the University of Toyama. YF is a professor of Kyoto University. AT is a graduate school student of Kyoto University.

\section{Acknowledgements}

We are grateful to Waseda University for allowing access to the Murono car test track. We thank Keisuke Yachi, Masashi Watanabe and Hiroki Sugawara of the University of Toyama for their help in the levelling. Lastly, we are most grateful to two anonymous reviewers for their constructive reviews and comments on the manuscript and to Taku Ozawa for his editorial advice and cooperation.

\section{Author details}

${ }^{1}$ Graduate School of Science and Engineering for Research (Science), University of Toyama, 3910 Gofuku, Toyama 930-8555, Japan. ²Department of Earth Science, Faculty of Science, University of Toyama, 3910 Gofuku, Toyama 930-8555, Japan. ${ }^{3}$ Department of Geophysics, Graduate School of Science, Kyoto University, Kitashirakawa Oiwake-cho, Sakyo-ku, Kyoto 606-8502, Japan.

\section{Received: 25 December 2014 Accepted: 1 April 2015}

\section{Published online: 17 April 2015}

\section{References}

Antonielli B, Monserrat O, Bonini M, Righini G, Sani F, Luzi G, Feyzullayev AA Aliyev CS (2014) Pre-eruptive ground deformation of Azerbaijan mud volcanoes detected through satellite radar interferometry (DInSAR). Tectonophysics 637:163-177, doi:10.1016/j.tecto.2014.10.005

Bonford G (2012) Geodesy. Hardpress Publishing, Miami

Bonini M (2007) Interrelations of mud volcanism, fluid venting, and thrust anticline folding: examples from the external northern Apennines (Emilia-Romagna, Italy). J Geophys Res 112, B08413, doi:10.1029/2006JB004859

Bonini M (2012) Mud volcanoes: indicators of stress orientation and tectonic controls. Earth-Sci Rev 115:121-152, doi:10.1016/j.earscirev.2012.09.002

Bonini M, Mazzarini F (2010) Mud volcanoes as potential indicators of regional stress and pressurized layer depth. Tectonophysics 494:32-47, doi:10.1016/jtecto.2010.08.006

Chigira M, Tanaka K (1997) Structural features and the history of mud volcanoes in southern Hokkaido, northern Japan. J Geol Soc Japan 103:781-791

Davies RJ, Brumm M, Manga M, Rubiandini R, Swarbrick R, Tingay M (2008) The East Java mud volcano (2006 to present): an earthquake or drilling trigger? Earth Planet Sci Lett 272:627-638, doi:10.1016/j.epsl.2008.05.029

Deville E, Guerlais SH (2009) Cyclic activity of mud volcanoes: evidences from Trinidad (SE Caribbean). Mar Petrol Geol 26:1681-1691, doi:10.1016/j.marpetgeo.2009.03.002

Dimitrov LI (2003) Mud volcanoes - a significant source of atmospheric methane. Geo-Mar Lett 23:155-161, doi:10.1007/s00367-003-0140-3

Etiope G, Milkov AV (2004) A new estimate of global methane flux from onshore and shallow submarine mud volcanoes to the atmosphere. Environ Geol 46:997-1002, doi:10.1007/s00254-004-1085-1

Etiope G, Lassey KR, Klusman RW, Boschi E (2008) Reappraisal of the fossil methane budget and related emission from geologic sources. Geophys Res Lett 35, L09307, doi:10.1029/2008GL033623
Fowler SR, Mildenhall J, Zalova S, Riley G, Elsley G, Desplanques A, Guliyev F (2000) Mud volcanoes and structural development on Shah Deniz. J Petrol Sci Eng 28:189-206

Japan Metrological Agency (2014) Hypocentre list. (in Japanese) In: Japan Metrological Agency web site. http://www.data.jma.go.jp/svd/eqev/data/ daily map/20141111.html - 20141127.html. Accessed 6 December 2014

Kusumoto S, Sudo K, Kawabata M, Uda T, Fukuda Y (2014) Vertical movement during the quiescent phase of the Murono mud volcano, Niigata, Japan. Earth Plan Space 66:14, doi:10.1186/1880-5981-66-14

Manga M, Brumm M, Rudolph ML (2009) Earthquake triggering of mud volcanoes. Mar Petrol Geol 26:1785-1798, doi:10.1016/j.marpetgeo.2009.01.019

Matta N, Hayakawa SY, Hori K, Kuo Y, Sugito N (2012) Uplift of the Matsudai mud volcano associated with the earthquake near the border of Nagano and Niigata Prefectures, measured by 3D laser scanner. Trans Jpn Geomorph Union 33:94-95 (in Japanese)

Mazzini A, Nermoen A, Krotkiewski M, Podladchikov Y, Planke S, Svensen H (2009a) Strike-slip faulting as a trigger mechanism for overpressure release through piercement structures. Implications for the Lusi mud volcano, Indonesia. Mar Petrol Geol 26:1751-1765, doi:10.1016/j.marpetgeo.2009.03.001

Mazzini A, Svensen H, Planke S, Guliyev I, Akhmanov GG, Fallik T, Banks D (2009b) When mud volcanoes sleep: insight from seep geochemistry at the Dashgil mud volcano, Azerbaijan. Mar Petrol Geol 26:1704-1715, doi:10.1016/j.marpetgeo.2008.11.003

Mellors R, Kilb D, Aliyev A, Gasanov A, Yetirmishli G (2007) Correlations between earthquakes and large mud volcano eruptions. J Geophys Res 112, B04304, doi:10.1029/2006JB004489

Morley CK (2007) Development of crestal normal faults associated with deepwater fold growth. J Struct Geol 29:1148-1163, doi:10.1016/j.jsg.2007.03.016

Noda H (1962) The geology and paleontology of the environs of Matsunoyama Niigata Prefecture, with reference to the so-called black shale. Sci Rep Tohoku Univ Ser 2(34):199-236

Onishi K, Sanada Y, Yokota T, Tokunaga T, Mogi K, Safani J, O'Neill A (2009) Investigation of subsurface $S$-wave velocity structures beneath a mud volcano in the Matsudai-Murono district by surface wave method. J Geogr 118:390-407 (in Japanese with English abstract)

Panahi BM (2005) Mud volcanism, geodynamics and seismicity of Azerbaijan and the Caspian Sea region. In: Martinelli G, Panahi B (eds) Mud volcanoes, geodynamics and seismicity. Springer, Berlin

Research Group for Active Faults (1991) The active faults in Japan: sheet maps and inventories, Revth edn. Univ. Tokyo press, Tokyo

Rudolph ML, Manga M (2010) Mud volcano response to the 4 April 2010 El MayorCucapah earthquake. J Geophys Res 115, B12211, doi:10.1029/2010JB007737

Sagiya T, Miyazaki S, Tada T (2000) Continuous GPS array and present-day crustal deformation of Japan. Pure Appl Geophys 157:2303-2322

Sawolo N, Sutriono E, Istadi BP, Darmoyo AB (2009) The LUSI mud volcano triggering controversy: was it caused by drilling? Mar Petrol Geol 26:1766-1784, doi:10.1016/j.marpetgeo.2009.04.002

Sawolo N, Sutriono E, Istadi BP, Darmoyo AB (2010) Was LUSI caused by drilling? - authors reply to discussion. Mar Petrol Geol 27:1658-1675, doi:10.1016/j.marpetgeo.2010.01.018

Takeuchi K, Yoshikawa T, Kamai T (2000) Geology of the Matsunoyama onsen district with geological map at 1:50,000. Geol Surv, Japan, Tsukuba, in Japanese with English abstract

Wang CY, Wong A, Dreger DS, Manga M (2006) Liquefaction limit during earthquakes and underground explosions: implications on ground-motion attenuation. Bull Seis Soc Am 96:355-363, doi:10.1785/0120050019 